\title{
Pemberian Fraksi Daun Kemangi (Ocimum americanum L.) terhadap Spermatozoa Tikus Putih Jantan (Rattus norvegicus)
}

\author{
Nora Novia Vinnata ${ }^{1}$, Salni $^{2}$, Sri Nita $^{3}$ \\ ${ }^{1,}$ Fakultas Ilmu Kesehatan, Universitas Katolik Musi Charitas, Indonesia \\ ${ }^{2,3}$ Fakultas Kedokteran, Universitas Sriwijaya, Indonesia \\ Email: norariyan.nn@gmail.com
}

\begin{abstract}
The Feeding Fractions of Kemangi Leaves (Ocimum americanum L.) on the Spermatozoa of White Rat (Rattus norvegicus). The major cause of a spermatogenetic process disorder in testis is free radical. One of the traditional medicines commonly used as an aphrodisiac is Kemangi plant. Rosary Basil leaf (Ocimum americanum L.), Indonesian name is Kemangi, contains active substances, such as flavonoid, saponin, tannin, and triterpenoid/steroid which is antioxidant and fertility. The purpose of the present research was to analyze the effect of testis weight, diameter, epithelium thickness, morphology, and spermatozoa amount of male white mouse (Rattus norvegicus) after feeding fractions of Kemangi leaf (Ocimum americanum L.) This study was experimental with a posttest-only control group design. The research sample size was 24 furrow male white mice Sprague Dawley, 60-74 days old. They were divided into 4 treatment groups, each being fed the fractions of $n$-hexane, ethyl acetate, and water-ethanol of Kemangi leaf at a dosage of $100 \mathrm{mg} / \mathrm{mouse} /$ day, compared to CMC $1 \%$ for the control group for 36 days, and then a dissection was done to take out secreted substances and to examine the histology of testis. The result showed that there were increases of testis weight in the treatment group as compared to that of the control $(p=0.018)$. In addition, there were increases in diameter and thickness of seminiferous tubule epithelium of testis, in the morphology of abnormal sperm $(\mathrm{p}=0.000)$, and in spermatozoa amount $(p=0.020)$. Fractions of Kemangi leaf can increase testis weight, diameter, and epithelium thickness, morphology, and spermatozoa amount of furrow male white mice Sprague Dawley, particularly the fraction of ethyl acetate.
\end{abstract}

Keywords: Fertility, Fraction, Kemangi/ rosary basil leaf, Spermatozoa

\begin{abstract}
Abstrak: Pemberian Fraksi Daun Kemangi (Ocimum americanum L.) terhadap Spermatozoa Tikus Putih Jantan (Rattus norvegicus). Penyebab utama dapat terganggunya proses spermatogenesis di dalam testis adanya radikal bebas, salah satu obat tradisional yang bisa digunakan sebagai afrodisiak yaitu tanaman kemangi. Daun Kemangi (Ocimum americanum L.) memiliki kandungan zat aktif seperti flavonoid, saponin, tanin, dan triterpenoid/steroid yang bersifat antioksidan dan fertilitas (penyubur). Penelitian bertujuan menganalisa pengaruh Berat, Diameter, Tebal Epitel Testis, Morfologi, dan Jumlah Spermatozoa Tikus Putih Jantan (Rattus norvegicus) setelah pemberian Fraksi Daun Kemangi. Penelitian ini merupakan penelitian experimental, rancangan post-test only control group design. Sampel penelitian ini sejumlah 24 tikus putih jantan galur Sprague Dawley usia 60-74 hari. Dibagi dalam 4 kelompok perlakuan dengan setiap kelompok diberi fraksi n-heksan, etil asetat, dan etanol air dari daun kemangi dengan dosis $100 \mathrm{mg} / \mathrm{ekor} / \mathrm{hr}$ dibandingkan dengan CMC 1\% untuk kelompok kontrol selama 36 hari dan dilakukan pembedahan untuk pengambilan sekret dan pemeriksaan histologi testis. Hasil penelitian menunjukkan peningkatan berat testis pada kelompok perlakuan dibanding kelompok kontrol $(p=0.018)$, terjadi juga peningkatan diameter, tebal epitel tubulus seminiferus testis, dan morfologi sperma abnormal $(p=0.000)$ dan pada jumlah spermatozoa $(p=0.020)$. Fraksi daun kemangi dapat meningkatkan berat, diameter, tebal epitel testis, morfologi dan jumlah spermatozoa tikus putih jantan galur Sprague Dawley terutama fraksi etil asetat.
\end{abstract}

Kata kunci: Fraksi, Daun kemangi, Fertilitas, Spermatozoa

Testis berukuran normal memiliki hubungan positif dengan potensi substansi fungsional (tubulus semineferus) yang terkandung di dalam testis. Fungsi reproduksi testis adalah berupa spermatozoa yang dihasilkan oleh bagian tubulus semineferus dari testis. Berat dan ukuran testis dapat digunakan sebagai indikator kuantitatif produksi spermatozoa (Melo 
et al, 2010). Menurut Hughes dan Acerini (2008), dalam sistem reproduksi jantan testis merupakan kelenjar utama yang bertanggung jawab terhadap produksi gamet jantan atau spermatozoa (spermatogenesis) dan sintesis hormon jantan atau androgen (steroidogenesis). Testis berjumlah sepasang, terletak di inguinal, tersimpan dalam kantung skrotum. Pada mammal, testis turun dan keluar dari rongga abdomen (peritoneal) menuju posisi ekstrakorporeal dan akhirnya masuk ke dalam skrotum (inguinoskrotal). Proses yang dikenal sebagai descensus testiculorum yang dikendalikan oleh androgen. Dengan posisi ini temperatur testis menjadi lebih rendah daripada temperatur tubuh (sekitar $2-4^{\circ} \mathrm{C}$ ) yang diperlukan untuk spermatogenesis.

Salah satu penyebab utama dapat terganggunya proses spermatogenesis di dalam testis yaitu adanya radikal bebas. Radikal bebas yang terbentuk di dalam tubuh dalam jumlah yang banyak akan merusak sel target seperti lipid, protein, karbohidrat, dan DNA (Abuja \& Albertini, 2001). Menurut Hadi (2011) kerusakan ini dapat menyebabkan produksi spermatozoa di dalam testis menjadi berkurang.

Penggunaan obat tradisional pada saat ini lebih diminati oleh masyarakat. Hal ini disebabkan masyarakat yang lebih memilih sehat dengan biaya yang relatif murah dan aman. Selain itu efek samping dari obat tradisional ini diyakini lebih kecil dan bahkan tidak ada jika dibandingkan dengan penggunaan bahan-bahan kimia atau obat modern. Salah satu tanaman yang digunakan sebagai obat tradisional dan afrodisiak (meningkatkan libido) yaitu kemangi. Tanaman ini menyegarkan, menghilangkan bau badan, bau mulut, menigkatkan system kekebalan tubuh. Tanaman beraroma wangi ini mengandung minyak atsiri (methilen alkohol, sineol, eugenol, linalool, nerol, thymol), karvakrol, asam ursolat, asam askorbat, kampene, betakarotin, tannin, terpineool, xilose, aldehida, alkaloida, flavonoida, asam-asam lemak (linoleat, linolenat, olet, palmitat, dan asam asesat), glikosida, mineral-mineral, pentosa, fenol, saponin, arginine, dan boron (Mangoting, dkk (2006) dalam Mardiana 2007).

Senyawa flavonoid dapat bekerja sebagai antioksidan yang dapat menghambat stress oksidatif (ketidakseimbangan antara radikal bebas dan antioksidan), mencegah kerusakan DNA, dan menangkal radikal bebas (Yang et al, 2006).

Salah satu penyebab utama terganggunya proses spermatogenesis di dalam testis adalah adanya radikal bebas. Radikal bebas juga dapat menghambat proses spermatogenesis karena sel leydig terganggu sehingga dapat menurunkan kadar sekresi hormon testosteron. Dampak negatif radikal bebas terhadap kesehatan reproduksi bisa diatasi dengan pemberian antioksidan (Ernawati, 2016).

Beberapa penelitian pendahuluan dari daun kemangi (Ocimum americanum L.) menunjukkan adanya fertilitas. Hal ini sesuai dengan penelitian yang dilakukan oleh Hutasuhut (2011) pemberian ekstrak etanol $70 \%$ herba kemangi (Ocimum americanum L.) pada tikus putih jantan strain Sprague-Dawley dengan dosis $1 \mathrm{mg} / \mathrm{kgbb}, 10$ $\mathrm{mg} / \mathrm{kgbb}$, dan $100 \mathrm{mg} / \mathrm{kgbb}$ dapat meningkatkan berat testis dan konsentrasi spermatozoa secara bermakna terhadap kontrol. Menurut Penelitian Murod (2014) Pemberian ekstrak air herba kemangi (Ocimum americanum L.) pada tikus jantan strain Sprague-Dawley dengan dosis 1 $\mathrm{mg} / \mathrm{kgbb}, \quad 10 \mathrm{mg} / \mathrm{kgbb}$, dan $100 \mathrm{mg} / \mathrm{kgbb}$ meningkatkan diameter tubulus semineferus dan sel germinal secara bermakna dibandingkan dengan kontrol. Hasil penelitian oleh Anzila, dkk (2017) pemberian ekstrak kemangi (Ocimum canum S) pada mencit jantan (Mus musculus) strain Balb-c dengan $200 \mathrm{mg} / \mathrm{kgbb}$ berpotensi dapat meningkatkan proses spermatogenesis atau sebagai agen fertilitas.

Berdasarkan latar belakang di atas ekstrak daun kemangi (Ocimum americanum L.) mempunyai efek fertilitas, sehingga peneliti mengambil judul "Pengaruh Pemberian Fraksi Daun Kemangi (Ocimum americanum L.) Terhadap Berat Testis, Diameter dan Tebal Epitel Tubulus Seminiferus, Morfologi dan Jumlah Spermatozoa Tikus Putih Jantan (Rattus norvegicus)".

\section{METODE}

Penelitian yang dilakukan merupakan penelitian eksperimental di Laboratorium Bagian Biologi Kedokteran FK Unsri, Laboratorium Fakultas MIPA Biologi Unsri, dan Laboratorium Patologi Anatomi Dyatnitalis. Rancangan penelitian yang digunakan adalah postest only control group design. Hewan uji yang digunakan dalam penelitian ini adalah tikus putih jantan strain Sprague Dawley ${ }^{\circledR}$ usia 60-74 hari sebanyak 24 ekor dengan berat badan 210-220 gram yang diperoleh dari Peternakan Bandung.

Perlakuan pada masing-masing kelompok tikus jantan adalah kelompok 1 sebagai kelompok kontrol $\left(\mathrm{K}_{1}\right)$ diberikan CMC $1 \% 2 \mathrm{ml}$ secara oral $1 \mathrm{x}$ per hari. Kelompok 2 sebagai kelompok perlakuan 1 (P1) diberikan fraksi n- 
heksan daun kemangi (Ocimum americanum L.) $100 \mathrm{mg} / \mathrm{kgbb} / \mathrm{hari}$, Kelompok 3 sebagai kelompok perlakuan 2 (P2) diberikan fraksi etil asetat daun kemangi (Ocimum americanum L.) $100 \mathrm{mg} / \mathrm{kgbb} / \mathrm{hari}$, Kelompok 4 sebagai kelompok perlakuan 3 (P3) diberikan fraksi etanol air daun kemangi (Ocimum americanum L.) $100 \mathrm{mg} / \mathrm{kgbb} / \mathrm{hari}$.

Proses ekstraksi simplisia daun kemangi (Ocimum americanum L.) sebanyak $1 \mathrm{Kg}$ dilakukan maserasi dengan pelarut etanol sebanyak 4 liter selama 2x24 jam di dalam alat ekstraktor kemudian disaring menggunakan kertas saring dan didapatkan hasil sebanyak 2750 $\mathrm{ml}$. Setelah itu dilakukan proses evaporasi yaitu larutan yang telah didiamkan dimasukkan dalam labu, labu evaporasi dipasang pada evaporator, dan water bath diisi dengan air sampai penuh kemudian dipanaskan diatur hingga suhu $70^{\circ} \mathrm{C}$ dan dibiarkan sampai larutan etanol memisah dengan zat aktif yang sudah ada dalam labu setelah itu dilanjutkan menggunakan penangas air. Ekstrak daun kemangi yang didapat sebanyak $600 \mathrm{ml}$ kemudian dimasukkan ke dalam gelas kaca.

Fraksinasi dilakukan untuk menarik macam-macam senyawa yang terkandung dalam ekstrak daun kemangi (Ocimum americanum L.) sesuai dengan kepolaranya, pelarut n-heksan akan melarutkan senyawa nonpolar, pelarut etil asetat akan melarutkan senyawa polar, dan pelarut etanol air akan melarutkan senyawa polar.

Proses fraksinasi dilakukan dengan metode FCC (fraksi cair-cair) yakni ekstrak aktif dimasukan ke dalam labu pisah dengan menggunakan pelarut yang sesuai menjadi 3 fraksi yaitu fraksi n-heksan, fraksi etil asetat, dan fraksi etanol. Dari ekstrak daun kemangi yang diperoleh dalam tahap ektraksi etanol ditambahakan dengan air perbandingan 1:1 yaitu sebanyak $600 \mathrm{ml}$ aquades dan etanol $600 \mathrm{ml}$. selanjutnya ditambahkan pelarut n-heksan sebanyak 3 L secara bertahap, setiap kali dimasukan sebanyak $750 \mathrm{ml} \mathrm{n}$-heksan dengan 4 kali pengulangan $(4 \times 750 \mathrm{ml})$.

Fraksi etanol dan n-heksan dipisahkan dengan labu pisah sehingga diperoleh fraksi $n$ heksan lalu diuapkan pada rotary evaporator, lalu di-hair dryer sampai mengental sehingga diperoleh fraksi berbentuk pasta. Fraksi etanol air dilanjutkan dengan penambahan pelarut etil asetat sebanyak 1,5 L secara bertahap, setiap kali dimasukan sebanyak 500 etil asetat dengan 3 kali pengulangan $(3 \times 500 \mathrm{ml})$ kemudian dipisahkan dengan labu pisah sehingga diperoleh fraksi etil asetat dan fraksi etanol setelah itu dilakukan penguapan pada rotary evapator lalu dihair dryer sampai mengental sehingga didapatkan fraksi berbentuk pasta.

Tahap akhir proses fraksinasi diperoleh tiga fraksi yaitu n-heksan, etil asetat, etanol dalam bentuk pasta. Lalu dilakukan penimbangan fraksi dengan cara timbanglah botol yang kosong sebelum diisi fraksi, selisih berat botol sebelum dan sesudah diberi fraksi adalah berat fraksi yang didapatkan. Ketiga tahap fraksi yang diperoleh diujikan dengan tikus jantan putih (Rattus norvegicus) untuk mengetahui fraksi aktif yang mempengaruhi perubahan testis, kualitas dan kuantitas spermatozoa.

\section{HASIL}

\section{Fraksinasi Daun Kemangi (Ocimum americanum $\mathrm{L}$.}

Tabel 1. Hasil Fraksinasi Ekstrak Kemangi

\begin{tabular}{lrr}
\hline Jenis Fraksi & \multicolumn{1}{c}{$\begin{array}{c}\text { Berat } \\
\text { Fraksi (g) }\end{array}$} & \multicolumn{1}{c}{$\begin{array}{c}\text { Presentase } \\
\text { Berat (\%) }\end{array}$} \\
\hline Fraksi n-heksan & 46,00 & 32,01 \\
Fraksi etil asetat & 38,30 & 26,65 \\
Fraksi etanol air & 59,40 & 41,33 \\
\hline Total & $\mathbf{1 4 3 , 7}$ & $\mathbf{1 0 0}$ \\
\hline
\end{tabular}

Dari Tabel 1 dapat dilihat bahwa hasil fraksinasi ekstrak daun kemangi didapat 59,40 gram $(41,33 \%)$ dengan pelarut polar etanol air, mempunyai berat yang lebih besar dibandingkan dengan 46,00 gram $(32,01 \%)$ n-heksan sebagai pelarut non polar dan 38,30 (26,65\%) etil asetat sebagai pelarut semi polar.

\section{Uji Screening Fitokimia}

Untuk mengetahui kelompok senyawa dalam fraksi daun kemangi (Ocimum americanum L.) dilakukan uji fitokimia, ini dilakukan sebagai screening awal dalam mengetahui kandungan metabolit sekunder pada sampel. Dilakukan 6 uji yaitu alkaloid, steroid, terpenoid, tanin, saponin, dan flavonoid dari masing-masing fraksi. Berdasarkan hasil uji Fitokimia menggunakan fraksi daun kemangi (Ocimum americanum L.) didapatkan hasil sebagai berikut: 
Tabel 2. Hasil Uji Skrining Fitokimia Fraksi Daun Kemangi (Ocimum americanum L.)

\begin{tabular}{lccc}
\hline $\begin{array}{c}\text { Senyawa } \\
\text { metabolik }\end{array}$ & $\begin{array}{c}\text { Fraksi n- } \\
\text { heksan }\end{array}$ & $\begin{array}{c}\text { Fraksi } \\
\text { etil asetat }\end{array}$ & $\begin{array}{c}\text { Fraksi } \\
\text { etanol air }\end{array}$ \\
\hline Alkaloid & - & - & - \\
\hline Steroid & - & + & + \\
\hline Terpenoid & - & + & + \\
\hline Tanin & + & - & - \\
\hline Saponin & + & + & + \\
\hline Flavonoid & + & + & + \\
\hline
\end{tabular}

Berdasarkan tabel 2 uji kualitatif komponen fitokimia daun kemangi menunjukkan bahwa fraksi daun kemangi (Ocimum americanum L.) pada fraksi n-heksan mengandung senyawa tanin, saponin, dan flavonoid, sedangkan pada etil acetat dan etanol air mengandung senyawa steroid, terpenoid, saponin, dan flavonoid.

\section{Karakeristik Sampel}

\section{Uji Homogenitas Berat Badan Tikus Putih} Jantan

Uji homogenitas dilakukan sebagai syarat untuk melakukan uji Anova. Hasil uji homogenitas berat badan tikus putih jantan dapat dilihat pada tabel di bawah ini:

Tabel 3. Uji Homogenitas Berat Badan Tikus Putih Jantan

\begin{tabular}{|c|c|c|c|}
\hline $\begin{array}{l}\text { Kelompok } \\
\text { Perlakuan }\end{array}$ & $\mathbf{n}$ & $\begin{array}{c}\text { Berat badan } \\
\text { Tikus(gram) } \\
\overline{\mathbf{x}} \pm \text { SD } \\
\end{array}$ & $\begin{array}{c}p- \\
\text { value }\end{array}$ \\
\hline CMC 1\% & 6 & $210,28 \pm 0,11$ & \multirow{4}{*}{0,326} \\
\hline Fraksi n-heksan & 6 & $210,32 \pm 0,12$ & \\
\hline Fraksi etil asetat & 6 & $210,44 \pm 0,13$ & \\
\hline Fraksi etanol air & 6 & $210,38 \pm 0,20$ & \\
\hline
\end{tabular}

Dari hasil karakteristik sampel berat badan tikus menunjukkan bahwa hasil uji statistik dengan menggunakan levene test didapatkan nilai $p=0,326$ ( $\mathrm{p}>0,05)$, hal ini menunjukkan bahwa tidak terdapat perbedaan rerata berat badan tikus pada setiap perlakuan atau dapat disimpulkan bahwa berat badan tikus homogen, sehingga tikus dapat digunakan dalam penelitian ini.

\section{Pengaruh Fraksi Daun Kemangi terhadap Berat Testis}

Pengaruh pemberian fraksi daun kemangi (Ocimum americanum L.) terhadap berat testis tikus putih jantan ( $R$. norvegicus) selama 36 hari, untuk melihat perbandingan berat testis antar kelompok dilakukan uji One Way Anova dan dilakukan uji lanjut Duncan didapatkan hasil sebagai berikut:

Tabel 4. Rata-Rata Berat Testis Tikus Putih Jantan Setelah Pemberian Fraksi Daun Kemangi Selama 36 Hari

\begin{tabular}{|c|c|c|c|}
\hline $\begin{array}{l}\text { Kelompok } \\
\text { Perlakuan }\end{array}$ & $\mathbf{n}$ & $\begin{array}{l}\text { Berat Testis } \\
(\text { gram) } \overline{\mathbf{x}} \pm \text { SD }\end{array}$ & $\begin{array}{c}p- \\
\text { value }\end{array}$ \\
\hline CMC 1\% & 6 & $1,31 \pm 0,17^{\mathrm{a}}$ & \multirow{4}{*}{0,018} \\
\hline Fraksi n-heksan & 6 & $1,47 \pm 0,19^{a b}$ & \\
\hline Fraksi etil asetat & 6 & $1,60 \pm 0,11^{b}$ & \\
\hline Fraksi etanol air & 6 & $1,55 \pm 0,10^{b}$ & \\
\hline
\end{tabular}

Keterangan: Angka-angka yang diikuti huruf kecil yang sama tidak berbeda nyata pada uji lanjut Duncan $(p<0,05)$

Pengaruh Pemberian Fraksi Daun Kemangi (Ocimum americanum L.) terhadap Diameter Tubulus Seminiferus Tikus Putih Jantan

Pengaruh pemberian fraksi daun kemangi (Ocimum americanum L.) terhadap diameter tubulus seminiferus testis tikus putih jantan $(R$. norvegicus) selama 36 hari, untuk melihat perbandingan diameter tubulus seminiferus testis antar kelompok dilakukan uji One Way Anova dan dilakukan uji lanjut Duncan didapatkan hasil sebagai berikut:

Tabel 5. Rata-Rata Diameter Tubulus Seminiferus Testis Tikus Putih Jantan setelah Pemberian Fraksi Daun Kemangi Selama 36 Hari

\begin{tabular}{|c|c|c|c|}
\hline $\begin{array}{l}\text { Kelompok } \\
\text { Perlakuan } \\
\end{array}$ & $\mathbf{n}$ & $\begin{array}{l}\text { Diameter Tubulus } \\
(\mu \mathrm{m}) \overline{\mathrm{x}} \pm \mathrm{SD}\end{array}$ & $\begin{array}{c}p \\
\text { value }\end{array}$ \\
\hline CMC $1 \%$ & 6 & $475,36 \pm 14,34^{a}$ & \multirow{4}{*}{0,000} \\
\hline Fraksi n-heksan & 6 & $497,47 \pm 28,90^{\mathrm{a}}$ & \\
\hline Fraksi etil asetat & 6 & $568,11 \pm 23,21^{\mathrm{c}}$ & \\
\hline Fraksi etanol air & 6 & $532,50 \pm 26,65^{b}$ & \\
\hline
\end{tabular}

Pengaruh Pemberian Fraksi Daun Kemangi (Ocimum americanum L.) terhadap Tebal Epitel Tubulus Seminiferus Testis Tikus Putih Jantan

Pengaruh pemberian fraksi daun kemangi (Ocimum americanum L.) terhadap tebal epitel tubulus seminiferus testis tikus putih jantan $(R$. norvegicus) selama 36 hari, untuk melihat perbandingan tebal epitel tubulus seminiferus testis antar kelompok dilakukan uji One Way Anova dan dilakukan uji lanjut Duncan didapatkan hasil sebagai berikut: 
Tabel 6. Rata-Rata Tebal Epitel Tubulus Seminiferus Tikus Putih Jantan setelah Pemberian Fraksi Daun Kemangi Selama 36 Hari

\begin{tabular}{lccr}
\hline $\begin{array}{c}\text { Kelompok } \\
\text { Perlakuan }\end{array}$ & n & $\begin{array}{c}\text { Tebal Epitel } \\
\text { Tubulus }(\boldsymbol{\mu m}) \\
\overline{\mathbf{x}} \pm \text { SD }\end{array}$ & $\begin{array}{c}\boldsymbol{p} \text { - } \\
\text { value }\end{array}$ \\
\hline CMC 1\% & 6 & $70,54 \pm 7,16^{\mathrm{a}}$ & \\
\cline { 1 - 2 } Fraksi n-heksan & 6 & $79,17 \pm 14,18^{\mathrm{a}}$ & \multirow{2}{*}{0,000} \\
\hline Fraksi etil asetat & 6 & $122,58 \pm 16,55^{\mathrm{b}}$ & \\
\hline Fraksi etanol air & 6 & $108,03 \pm 20,56^{\mathrm{b}}$ & \\
\hline
\end{tabular}

Keterangan: Angka-angka yang diikuti huruf kecil yang sama tidak berbeda nyata pada uji lanjut Duncan $(p<0,05)$

Pengaruh Pemberian Fraksi Daun Kemangi (Ocimum americanum L.) terhadap Morfologi Spermatozoa Tikus Putih Jantan

Pengaruh pemberian fraksi daun kemangi (Ocimum americanum L.) terhadap morfologi spermatozoa abnormal tikus putih jantan $(R$. norvegicus) selama 36 hari, untuk melihat perbandingan morfologi spermatozoa abnormal antar kelompok dilakukan uji One Way Anova dan dilakukan uji lanjut Duncan didapatkan hasil sebagai berikut:

Tabel 7. Rata-Rata Morfologi Sperma Abnormal Tikus Putih Jantan setelah Pemberian Fraksi Daun Kemangi Selama 36 Hari

\begin{tabular}{llcll}
\hline $\begin{array}{c}\text { Kelompok } \\
\text { Perlakuan }\end{array}$ & n & $\begin{array}{c}\text { Morfologi Sperma } \\
\text { Abnormal (\%) } \\
\overline{\mathbf{x}} \pm \text { SD }\end{array}$ & $\begin{array}{c}\boldsymbol{p} \\
\text { value }\end{array}$ \\
\cline { 1 - 3 } CMC 1\% & 6 & $46.00 \pm 1,26^{\mathrm{b}}$ & \\
\cline { 1 - 3 } Fraksi n-heksan & 6 & $44,83 \pm 6,76^{\mathrm{b}}$ & \multirow{2}{*}{0,000} \\
\cline { 1 - 3 } Fraksi etil asetat & 6 & $32,00 \pm 1,89^{\mathrm{a}}$ & \\
\cline { 1 - 2 } Fraksi etanol air & 6 & $42,00 \pm 1,09^{\mathrm{b}}$ & \\
\cline { 1 - 2 } $\begin{array}{l}\text { Keterangan: Angka-angka yang diikuti huruf kecil yang } \\
\text { sama tidak berbeda nyata pada uji lanjut Duncan }(p<0,05)\end{array}$
\end{tabular}

\section{Pengaruh Pemberian Fraksi Daun Kemangi} (Ocimum americanum L.) terhadap Jumlah Spermatozoa Tikus Putih Jantan

Pengaruh pemberian fraksi daun kemangi (Ocimum americanum L.) terhadap jumlah spermatozoa tikus putih jantan ( $R$. norvegicus) selama 36 hari, untuk melihat perbandingan jumlah spermatozoa antar kelompok dilakukan uji One Way Anova dan dilakukan uji lanjut Duncan didapatkan hasil sebagai berikut:
Tabel 8. Rata-Rata Jumlah Sperma Tikus Putih Jantan setelah Pemberian Fraksi Daun Kemangi selama 36 Hari

\begin{tabular}{lcccc}
\hline $\begin{array}{l}\text { Kelompok } \\
\text { Perlakuan }\end{array}$ & n & $\begin{array}{c}\text { Jumlah Sperma } \\
(\mathbf{J u t a} / \mathbf{m l}) \\
\overline{\mathbf{x}} \pm \mathbf{S D}\end{array}$ & p-value \\
\hline CMC 1\% & 6 & $179,72 \pm 42,09^{\mathrm{a}}$ & \\
\hline Fraksi n-heksan & 6 & $216,69 \pm 43,54^{\mathrm{ab}}$ & & 0,020 \\
\hline Fraksi etil asetat & 6 & $280,88 \pm 69,70^{\mathrm{b}}$ & \\
\hline Fraksi etanol air & 6 & $266,11 \pm 64,12^{\mathrm{b}}$ & \\
\hline
\end{tabular}

Keterangan: Angka-angka yang diikuti huruf kecil yang sama tidak berbeda nyata pada uji lanjut Duncan $(p<0,05)$

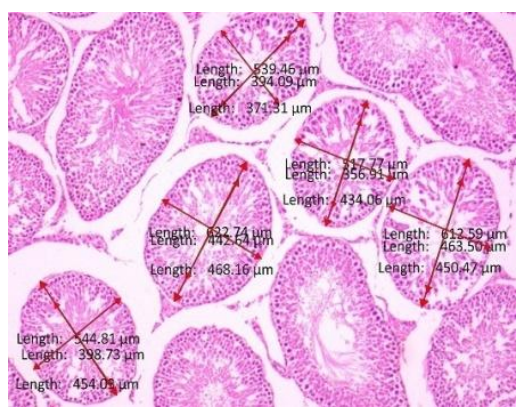

(A)

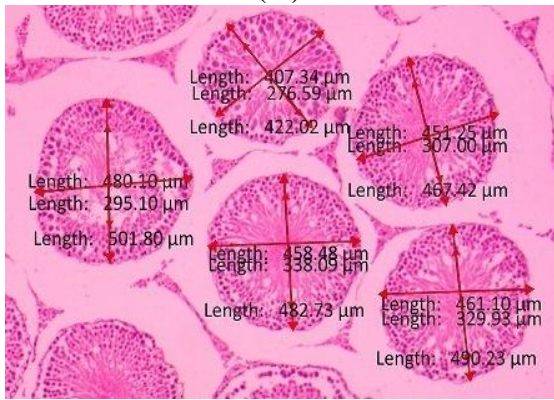

(B)

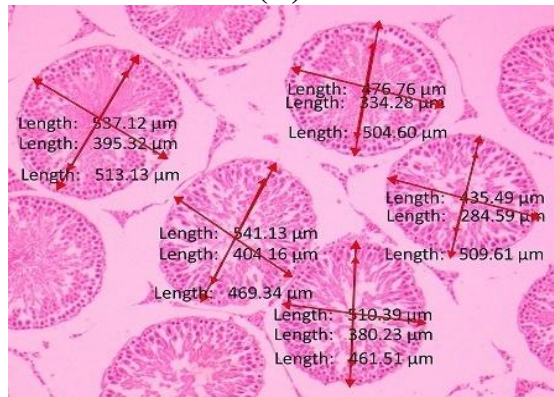

(C)

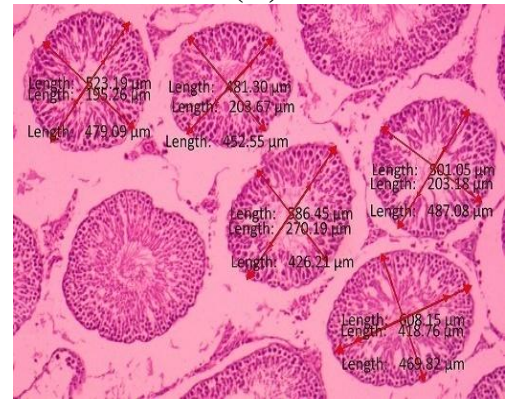

(D)

Gambar 1. Penampang histologis testis pemotongan melintang; (A) Tebal Epitel dan diameter testis kontrol; (B) setelah diberi fraksi etil acetat; (C) fraksi n-heksan; (D) fraksi etanol air (Perbesaran $100 \mathrm{X}$ ) 


\section{PEMBAHASAN}

Ekstraksi, Fraksinasi dan Golongan Senyawa Daun Kemangi (Ocimum americanum L.)

Dalam penelitian ini hasil fraksinasi diperoleh fraksi n-heksan sebanyak 46,00 gram, fraksi etil asetat sebanyak 38,30 gram dan fraksi etanol air sebanyak 59,40 gram. Masing-masing hasil fraksi tersebut dilakukan uji skrining fitokimia yang tujuannya untuk melihat dan menentukan golongan senyawa yang terkandung dari fraksi. Berdasarkan uji kualitatif senyawa fitokimia daun kemangi menunjukkan bahwa fraksi daun kemangi (Ocimum americanum L) pada fraksi n-heksan mengandung senyawa tanin, saponin dan flavonoid, sedangkan pada fraksi etil acetat dan etanol air mengandung senyawa steroid, terpenoid, saponin, dan flavonoid. Kedua fraksi tersebut mempunyai nilai uji yang sama, tetapi hasil perlakuan dalam penelitian ini lebih besar pengaruh yang diberikan oleh fraksi etil asetat dibanding etanol air hal tersebut ditunjukkan dengan hasil analisis data menggunakan uji Anova, diduga karena konsentrasi atau kadar larutan di dalam fraksi etil asetat lebih besar dibandingkan etanol air. Hal ini sesuai dengan pendapat Pratimasari (2009) semakin besar konsentrasi maka terjadi peningkatan persen inhibisi pada fraksi. Sehingga dapat disimpulkan pula pada penelitian ini sesuai urutan fraksi yang lebih mempunyai pengaruh yaitu fraksi etil asetat, dilanjutkan dengan fraksi etanol air dan terakhir adalah fraksi n-heksan. Kandungan kimia pada Ocimum americanum L., antara lain: minyak atsiri, karbohidrat, fitosterol, alkaloid, senyawa fenolik, tanin, lignin, pati, saponin, flavonoid, steroid, terpenoid, dan antrakuinon (Sarma \& Babu, 2011). Dalam fraksi-fraksi daun kemangi terdapat beberapa senyawa golongan fenolik, seperti tanin dan flavonoid senyawa-senyawa ini bersifat antioksidan dan dapat meningkatkan sekresi hormon.

Salah satu tumbuhan yang dapat digunakan sebagai antioksidan alami adalah tanaman dari Genus Ocimum yaitu tanaman kemangi yang termasuk ke dalam family Lamiaceae dikarenakan banyaknya manfaat tanaman tersebut bagi kesehatan (Balaji et al, 2011) dalam hal ini sesuai dengan hasil screening uji fitokimia yang dilakukan.
Pengaruh Pemberian Fraksi Daun Kemangi (Ocimum americanum L.) terhadap Berat Testis Tikus Putih Jantan

Berdasarkan hasil uji ANOVA dapat disimpulkan bahwa pemberian fraksi daun kemangi dengan dosis $100 \mathrm{mg} / \mathrm{kgBB}$ memiliki pengaruh untuk meningkatkan berat testis pada tikus putih jantan. Hal ini dapat dilihat dari ratarata berat testis pada kelompok perlakuan mengalami peningkatan dari kelompok CMC $1 \%$. Untuk melihat signifikansi antar kelompok perlakuan maka dilakukan uji lanjut Duncan yang menunjukkan bahwa terjadi peningkatan berat testis, berat testis pada kelompok perlakuan fraksi n-heksan, etil asetat dan etanol air berbeda nyata dibandingkan kelompok CMC $1 \%$, sedangkan fraksi n-heksan, etil asetat, dan etanol air tidak berbeda bermakna, fraksi etil asetat lebih efektif dalam meningkatkan berat testis.

Berdasarkan uji ANOVA terdapat perbedaan nyata pada berat testis. Peningkatan berat testis akibat perlakuan fraksi-fraksi diduga oleh senyawa-senyawa yang terkandung di dalam fraksi yang akan meningkatkan produksi spermatozoa dan hormon testosteron. Hormon testosteron berperan penting dalam proses pembentukan spermatozoa melalui spermatogenesis di dalam testis serta pematangan sperma dalam epididimis (Sukmaningsih, 2012).

Hal ini sesuai dengan penelitian yang dilakukan oleh Hutasuhut (2014) berdasarkan hasil uji normalitas Kolmogorov-Smirnov dan homogenitas Levene, pemberian ekstrak herba kemangi dengan dosis $1 \mathrm{mg} / \mathrm{kgBB}, 10 \mathrm{mg} / \mathrm{kgBB}$ dan $100 \mathrm{mg} / \mathrm{kgBB}$ dapat meningkatkan berat testis. Testis berukuran normal lebih memiliki hubungan positif dengan potensi substansi fungsional (tubulus seminiferus) yang terkandung di dalam testis. Fungsi reproduksi testis adalah berupa produksi spermatozoa yang dihasilkan oleh bagian tubulus seminiferus dari testis. Berat dan ukuran testis dapat digunakan sebagai indikator kuantitatif produksi spermatozoa (Melo et al, 2010).

\section{Pengaruh Pemberian Fraksi Daun Kemangi (Ocimum americanum L.) terhadap Diameter Tubulus Seminiferus Testis Tikus Putih Jantan}

Berdasarkan hasil uji ANOVA menunjukkan bahwa terdapat perbedaan yang bermakna rerata diameter tubulus seminiferus testis antar kelompok perlakuan fraksi daun kemangi (Ocimum americanum L.). Untuk melihat signifikansi antar kelompok perlakuan maka 
dilakukan uji lanjut dengan menggunakan uji Duncan didapatkan bahwa CMC $1 \%$ dan Nheksan tidak berbeda bermakna dibandingkan etil asetat dan etanol air dalam meningkatkan diameter tubulus, sedangkan etil asetat dan etanol air terdapat perbedaaan nyata namun etil asetat lebih efektif dalam meningkatkan diameter tubulus pada tikus putih jantan.

Dari hasil penelitian di atas dapat diketahui bahwa fraksi etil asetat dapat memengaruhi proses spermatogenesis yang ditunjukkan oleh perubahan berat testis yang diikuti perubahan diameter tubulus seminiferus. Diduga disebabkan dari kandungan senyawa steroid yang ada pada fraksi etil asetat. Kandungan senyawa steroid dapat meningkatkan sekresi hormon testosteron. Hormon testosteron merupakan hormon steroid yang di produksi oleh sel Leydig di bawah pengaruh Luteinizing Hormone (LH) (Guyton, 1998). LH berfungsi untuk merangsang sel Leydig yang mensintesis hormon testosteron sehingga hormon testosteron tersebut bereaksi dengan baik dalam proses spermatogenesis.

Hasil penelitian ini sesuai dengan penelitian yang dilakukan oleh Anzila (2017) pemberian ekstrak kemangi berpotensi dapat meningkatkan sekresi hormon testosteron, proses spermatogenesis, atau sebagai agen fertilitas. Begitupula hasil penelitian yang dilakukan oleh Murod (2014) pemberian ekstrak air herba kemangi pada dosis $1 \mathrm{mg} / \mathrm{KgBB}, 10 \mathrm{mg} / \mathrm{KgBB}$ dan $100 \mathrm{mg} / \mathrm{KgBB}$ dapat meningkatkan diameter tubulus seminiferus. Adanya pembentukan GnRH (Gonadotropin Releasing Hormone) yang dihasilkan oleh hipotalamus akan menimbulkan pelepasan FSH dan LH. FSH berfungsi untuk pematangan sperma oleh sel sertoli di dalam testis. FSH berkaitan dengan reseptor spesifik FSH yang berada melekat di dekat sel sertoli di dalam tubulus seminiferus. FSH inilah yang akan mengakibatkan sel sertoli untuk tumbuh dan menghasilkan unsur-unsur yang dibutuhkan dalam proses spermatogenik (Guyton, 2012). Mengingat bahwa kadar testosteron pada hormon steroid memiliki hubungan dengan LH dan FSH, seperti peningkatan kadar gonadotropin bersamaan dengan peningkatan kadar testosteron, maka proses spermatogenesis yang terjadi semakin meningkat.

\section{Pengaruh Pemberian Fraksi Daun Kemangi (Ocimum americanum L.) terhadap Tebal Epitel Tubulus Seminiferus Testis Tikus Putih Jantan}

Berdasarkan hasil uji ANOVA dapat disimpulkan bahwa pemberian fraksi daun kemangi dengan dosis $100 \mathrm{mg} / \mathrm{kgBB}$ memiliki pengaruh untuk meningkatkan tebal epitel tubulus pada tikus putih jantan. Hal ini dapat dilihat dari rata-rata tebal epitel tubulus pada kelompok perlakuan mengalami peningkatan dari kelompok kontrol (CMC 1\%). Untuk melihat signifikansi antar kelompok maka dilakukan uji lanjut dengan menggunakan uji Duncan bahwa CMC 1\% dan n-heksan tidak berbeda bermakna atau mempunyai efek yang sama dalam meningkatkan tebal epitel tubulus dan terdapat perbedaan nyata dibandingkan dengan etil asetat dan etanol air, sedangkan etil asetat dan etanol air tidak terdapat perbedaan bermakna, etil asetat dalam meningkatkan tebal epitel tubulus tikus putih jantan lebih efektif.

Dari hasil screening fitokimia diketahui bahwa fraksi etil asetat mengandung senyawa fenol yaitu flavonoid yang dapat mempengaruhi proses spermatogenesis yang ditunjukkan oleh perubahan diameter tubulus seminiferus yang diikuti dengan tebal epitel tubulus. Flavonoid memiliki kemampuan sebagai antioksidan yang dapat menghambat OS (Stres Oksidatif), melawan bahaya radikal bebas dan meningkatkan proses spermatogenesis. Pengaruh flavonoid juga dapat meningkatkan proses regenerasi dari sel, flavonoid meningkatkan proses regenerasi dengan cara mendestruksi radikal bebas, menyediakan substrat kompetitif untuk lipid tak jenuh dalam membran dan atau mempercepat mekanisme perbaikan membran sel yang rusak (Sharma, 2011) sehingga hal tersebut diduga mempunyai keselarasan dengan meningkatnya diameter tubulus dilihat dari meningkatnya jumlah sel spermatogenik juga dapat terjadi penebalan epitel tubulus seminiferus.

Hal ini sesuai dengan penelitian Murod (2014) yang mengatakan bahwa peningkatan dalam proses spermatogenesis yang terlihat pada tebal epitel sel germinal berhubungan erat dengan aktivitas senyawa yang terkandung dalam ekstrak air herba kemangi, dari hasil penapisan fitokimia, ekstrak air herba kemangi menunjukkan terdapat senyawa tannin dan flavonoid, senyawa-senyawa tersebut telah dilaporkan pada beberapa penelitian dapat meningkatkan proses spermatogenesis dengan berbagai mekanisme yang berbeda-beda.

Dijelaskan lanjut menurut Agarwal et al. (2005) di dalam Murod (2014), salah satu faktor yang berpengaruh terhadap tingkat kesuburan pria yaitu stres oksidatif $(O S)$. Stres oksidatif dapat terjadi ketika Reactive Oxygen Species (ROS) diproduksi secara berlebihan atau terjadi gangguan mekanisme pertahanan antioksidan sehingga berbahaya bagi spermatozoa. 
Spermatozoa rentan terhadap ROS karena pada membran plasma dan sitoplasma mengandung sejumlah besar asam lemak tak jenuh ganda sehingga rentan terhadap peroksidasi lipid. ROS merupakan metabolit yang berasal dari oksigen dimana dapat memodifikasi fungsi sel dan membahayakan kelangsungan hidup sel. Hal ini yang menunjukkan bahwa salah satu mekanisme antioksidan dari flavonoid adalah mencegah terbentuknya ROS (Reactive Oxygen Species) oleh flavonoid dilakukan dengan cara mencegah reaksi redoks yang dapat menghasilkan radikan bebas yang baru (Hardiningtyas et al, 2014).

\section{Pengaruh Pemberian Fraksi Daun Kemangi (Ocimum americanum L.) terhadap Morfologi Spermatozoa Tikus Putih Jantan}

Berdasarkan hasil uji ANOVA dapat disimpulkan bahwa pemberian fraksi daun kemangi dengan dosis $100 \mathrm{mg} / \mathrm{kgBB}$ memiliki pengaruh dalam menurunkan morfologi abnormal pada tikus putih jantan. Hal ini dapat dilihat dari rata-rata morfologi pada kelompok perlakuan mengalami penurunan morfologi abnormal dari kelompok CMC 1\%. Pada hasil uji lanjut dengan menggunakan uji Duncan didapatkan bahwa kelompok perlakuan etil asetat berbeda nyata dibandingkan kelompok CMC $1 \%$, n-heksan dan etanol air. Fraksi etil asetat lebih efektif dalam menurunkan morfologi sperma abnormal. Diketahui bahwa pada senyawa flavonoid memiliki fungsi sebagai antioksidan.

Antioksidan adalah zat yang dapat melawan pengaruh bahaya radikal bebas yang terbentuk sebagai hasil metabolisme oksidatif dengan cara memberikan satu elektronnya kepada radikal bebas sehingga menjadi non radikal (Rohmatussolihat, 2009). Hal ini sejalan berdasarkan penelitian yang dilakukan oleh Murod (2014), pemberian ekstrak herba kemangi (Ocimum americanum L.) pada tikus jantan Sprague Dawley dengan dosis $1 \mathrm{mg} / \mathrm{KgBB}, 10$ $\mathrm{mg} / \mathrm{KgBB}$, dan $100 \mathrm{mg} / \mathrm{KgBB}$ dapat menurunkan abnormalitas morfologi sperma secara bermakna dibandingkan kontrol. Data rata-rata morfologi sperma abnormal didapat dengan cara melihat apusan sperma di bawah mikroskop dengan perbesaran 400x, morfologi abnormal yang diamati diantaranya adalah leher patah, tanpa kepala, kepala rangkap, tanpa ekor, dan ekor patah.

Sejalan dengan pendapat Rahardhianto et al (2012) mengatakan bahwa struktur morfologi yang normal berkaitan dengan spermatogenesis yang menghasilkan sel-sel spermatozoa normal untuk mendukung daya geraknya sehingga dapat masuk ke organ reproduksi betina. Spermatogenesis dapat terjadi melalui beberapa tahap pembelahan. Tahap awalnya spermatogonia akan mengalami perubahan menjadi spermatosit primer, kemudian menjadi spermatosit sekunder, dan menjadi spermatid. Sebelum spermatid menjadi spermatozoa ada fase yang dilewati spermatid yang disebut fase spermiogenesis. Fase ini terdiri dari fase golgi, akrosom, dan pematangan bertujuan untuk membentuk morfologi normal spermatozoa yang terdiri dari kepala, leher dan ekor yang normal. (Rugh, 1997).

\section{Pengaruh Pemberian Fraksi Daun Kemangi (Ocimum americanum L.) terhadap Jumlah Spermatozoa Tikus Putih Jantan}

Berdasarkan hasil uji ANOVA dapat disimpulkan bahwa pemberian fraksi daun kemangi dengan dosis $100 \mathrm{mg} / \mathrm{kgBB}$ memiliki pengaruh dalam meningkatkan jumlah sperma pada tikus putih jantan. Hal ini dapat dilihat dari rata-rata jumlah spermatozoa pada kelompok perlakuan mengalami peningkatan dari kelompok CMC 1\%. Dari hasil uji lanjut dengan menggunakan Duncan menunjukkan bahwa terjadi peningkatan jumlah spermatozoa. Peningkatan jumlah spermatozoa pada kelompok perlakuan fraksi etil asetat, n-heksan, dan etanol air terdapat perbedaan nyata dengan CMC $1 \%$, sedangkan kelompok perlakuan fraksi etil asetat, n-heksan, dan etanol air tidak terdapat perbedaan bermakna, pada kelompok fraksi etil asetat dalam meningkatkan jumlah spermatozoa lebih efektif.

Senyawa flavonoid pada fraksi etil asetat bekerja sebagai antioksidan yang diduga dapat meningkatkan produksi dan jumlah spermatozoa. Kandungan senyawa kimia dalam herba kemangi adalah 1,8 sineol, anethol, apigenin, fenkhona, stigmasterol, tritofan, tannin, sterol dan boron (Dharmayanti, 2003) serta minyak atsiri, pati, lignin, fitosterol, alkaloid, senyawa fenolik, saponin, flavonoid, terpenoid, dan antrakuinon (Sarma dan Babu, 2011). Hal ini sesuai dengan penelitian yang dilakukan oleh Safwan (2016) yang mengatakan ekstrak daun kemangi dapat meningkatkan jumlah spermatozoa. Sedangkan hasil penelitian oleh Hutasuhut (2014) pemberian ekstrak herba kemangi pada dosis $100 \mathrm{mg} / \mathrm{KgBB}$ dapat meningkatkan konsentrasi jumlah spermatozoa secara bermakna terhadap kontrol.

Jumlah spermatozoa yang dihasilkan sangat tergantung pada proses yang berlangsung terjadi selama proses spermatogenesis dalam tubulus seminiferus. Bila spermatogenesis berlangsung normal maka 
akan dihasilkan jumlah spermatozoa yang normal. Sebaliknya jika selama proses spermatogenesis terjadi gangguan, maka perkembangan sel spermatogonium akan mempengaruhi jumlah spermatozoa yang terbentuk. Hal ini sangat tergantung pada besarnya gangguan yang terjadi selama proses spermatogenesis.

\section{SIMPULAN}

Berdasarkan hasil yang dilakukan bahwa penelitian ini hanya berlaku pada tikus yaitu tentang perubahan berat, diameter, dan tebal epitel testis tikus putih jantan ( $R$. norvergicus) akibat pemberian fraksi daun kemangi (Ocimum americanum L.) dengan dosis $100 \mathrm{mg} /$ ekor/hari selama 36 hari dapat disimpulkan bahwa fraksi

\section{DAFTAR PUSTAKA}

Abuja, P. M., \& Albertini, R. 2001. Methods for monitoring oxidative stress, lipid peroxidation and oxidation resistance of lipoproteins. Clinica chimica acta, 306(12), 1-17.

Agarwal A, Prabakaran SA. 2005. Mechonism, Mesurement and prevention of oxidative stress in male reproductive physiology. Indian journal of experimental. Biology43

Anzila, I., WM, A. P., Soewondo, A., \& Rahayu, S. 2017. Pengaruh Ekstrak Ethanol Kemangi (Ocimum canum Sims.) terhadap Struktur Histologi Testis Mencit (Mus musculus) Jantan. Biotropika: Journal of Tropical Biology, 5(1), 22-26.

Balaji, R., Prakash, G., Suganya, P. D., \& Aravinthan, K. M. 2011. Antioxidant activity of methanol extract of Ocimum tenuiflorum (dried leaf and stem). Int $J$ Pharm Sci Rev Res, 3, 20-7.

Dharmayanti, S. 2003. Berbagai Khasiat Herba Kemangi.

https://minyakatsiriindonesia.wordpress.co $\mathrm{m} /$ minyak-kemangi/artikel/ (10 September 2017).

Ernawati, E., \& Nurliani, A. 2016. Efek Antioksidan Ekstrak Etanol Bulbus Bawang Dayak (Eleutherine Americana Merr.) terhadap Struktur Mikroanatomi Tubulus Seminiferus Testis Tikus yang Dipapar Asap Rokok. Jurnal Sains dan Terapan Kimia, 6(2), 93-100. daun kemangi (Ocimum americanum L.) berpengaruh dalam meningkatkan berat testis, tebal epitel dan diameter tubulus seiniferus, morfologi, dan jumlah spermatozoa pada tikus putih jantan (Rattus norvegicus) terutama fraksi etil asetat

\section{SARAN}

Perlu dilakukan penelitian tentang pengaruh pemberian fraksi daun kemangi (Ocimum americanum L.) terhadap kadar hormon (FSH, LH, dan testosteron dalam serum darah) dan penelitian lebih lanjut mengenai perbandingan antara dosis pada fraksi efektif etil asetat dengan dosis obat yang digunakan sebagai agen fertilitas.
Guyton, A.C. 1998. Fisiologi Kedokteran. Edisi V, diterjemahkan oleh Ady Dharma, Jakarta: Penerbit Buku Kedokteran EGC.

Guyton A.C, Hall J.E. 2012. Buku Ajar Fissiologi Kedokteran. Edisi 11. Jakarta : Penerbit Buku Kedokteran EGC

Hadi, R.S. 2011. Apoptosis pada Sperma Sebagai Pertanda Adanya Gangguan Kesuburan Pria. Majalah Kesehatan PharmaMedika. Vol 3 (2).

Hardiningtyas, S. D., Purwaningsih, S., \& Handharyani, E. 2014. Aktivitas antioksidan dan efek hepatoprotektif daun bakau api-api putih. Jurnal Pengolahan Hasil Perikanan Indonesia, 17(1).

Hughes, I. A., \& Acerini, C. L. 2008. Factors controlling testis descent. European Journal of Endocrinology, 159(suppl 1), S75-S82.

Hutasuhut R, 2014, Uji Aktivitas Ekstrak Etanol $70 \%$ Herba Kemangi (Ocimum snactum L.) terhadap kualitas sperma dan densitas sel spermatogenik tikus sprague-dawley jantan secara in vivo. [Skripsi]. Jakarta: UIN Syarif Hidayatullah Jakarta.

Mardiana, Lina dan R., Paimin, Fendy. 2007. Ramuan tradisional untuk kesuburan suami istri, Cet 3. Jakarta: Penebar swadaya.

Melo, et al. 2010. Patient with chronic myeloid leukimia who maintain a complete molecular response after stopping imatinib treatment have evidence of persistent 
leukimia by DNA PCR. J Blood Cancer, 24.

Murod, A. M. 2014. Uji Aktivitas Ekstrak Air Herba Kemangi (Ocimum Americanum L.) terhadap Kualitas Sperma Dan Densitas Sel Spermatogenesis Tikus Sprague-Dawley Jantan secara In Vivo. [Skripsi]. Jakarta: Program Studi Farmasi, UIN Syjarif Hidatullah.

Pratimasari D. 2009. Uji Aktivitas Penangkap Radikal Buah Carica Papaya L. dengan Metode DPPH dan Penetapan Kadar Fenolik serta Flavonoid Totalnya. [Skripsi]. Surakarta: Fakultas Farmasi, Universitas Muhammadiyah Surakarta.

Rahardhianto, A., Abdulgani, N., Trisyani, N. 2012. Pengaruh Konsentrasi Larutan Madu dalam $\mathrm{NaCl}$ Fisiologis terhadap Viabilitas dan Motilitas Spermatozoa Ikan Patin (Pangasius pangasius) selama Masa Penyimpanan. Jurnal Sains dan Seni ITS. Vol.1 (1): 58-63.

Rohmatussolihat. 2009. Antioksidan, Penyelamat sel-sel Tubuh Manusia. BioTrends.
Safwan, Taufan, Sugara Mutiara Kusuma Rohmi. 2016. Pengaruh ekstrak daun kemangi terhadap motilitas dan konsentrasi spermatozoa mencit jantan (Mus musculus). Jurnal Ilmiah Ibnu Sina.

Sarma D, Sai Koteswar and Babu, A. Venka Suresh. 2011. Pharmacognostic and Phytochemical Studies of Ocimum americanum. Jurnal of Chemical and Pharmaceutical Research. Volume 3. Nomor 3

Sharma N, dkk. 2013. An Analysis of Basil (Ocimum sp) to Study the Morphological Variability. Indian Journal of Fundamental and Applied Life Science.

Sukandar, D, 2015. Flavonoid terpenilasi dari kayu batang tumbuhan artocarpus champeden spreng. Bandung: Institut Teknologi Bandung

Sukmaningsih, A, A SG. A, Ermayanti. 2012 Gangguan Spermatogenesis setelah pemberian monosodium Glutamamt pada Mencit. Jurnal Biologi. 